\title{
Automation Potential in the Remanufacturing of Electric and Electronic Equipment (EEE)
}

\author{
Erik SUNDIN $^{\mathrm{a}, 1}$, Björn BACKMAN ${ }^{\mathrm{b}}$, Kerstin JOHANSEN ${ }^{\mathrm{a}, \mathrm{c}}$, \\ Martin HOCHWALLNER ${ }^{\mathrm{a}}$, Steffen LANDSCHEIDT ${ }^{\mathrm{d}}$ and Sasha SHAHBAZI ${ }^{\mathrm{b}}$ \\ ${ }^{a}$ Division of Manufacturing Engineering, Department of Management and Engineering, \\ Linköping University, Linköping 58183, Sweden \\ ${ }^{b}$ Research Institutes of Sweden (RISE) \\ ${ }^{c}$ Department of Industrial Product development, Production and Design, \\ Jönköping University, Jönköping. \\ ${ }^{d}$ Department of Forestry and Wood Technology, Linnaeus University, Växjö.
}

\begin{abstract}
Remanufacturing is the industrial process of returning used products (cores) to a like-new or better condition. During this industrial process, the cores go through several process steps, e.g., inspection, disassembly, cleaning, reprocess (repairs), storage, reassembly and final testing. Manufacturing companies also see remanufacturing as a way to become more circular and sustainable in economic, environmental and social terms. Technological advancements within the robot industry have increased the possibilities for using more automation within the remanufacturing industry, while recently, the remanufacturing of electric and electronic equipment (EEE) has grown around the world. This paper aims to identify the automation potentials of the remanufacturing of EEE. A multiple case study at four EEE remanufacturing companies was conducted to meet this aim. The case study, along with previous research, shows examples of EEE remanufacturing steps that are mainly performed manually. The results from this research show the possible automation potential for the process steps of cleaning, disassembly and reassembly at the four remanufacturing case companies.
\end{abstract}

Keywords. Automation, Remanufacturing, Work environment, HRC, SME

\section{Introduction}

The circular economy is a means towards sustainable development, and it is estimated that a shift from a linear to a circular economy would generate total annual benefits for Europe of around $€ 1.8$ trillion [1]. Remanufacturing has an essential role within the circular economy [2], one which enables the shift to a circular economy, as this activity gets used products back on the market instead of being scrapped. Remanufacturing is an industrial process whereby products are restored to like-new condition. According to the World Economic Forum [3], advanced remanufacturing is one of the production areas that industry should focus on in the near future. In addition, the remanufacturing industry

\footnotetext{
${ }^{1}$ Corresponding Author. erik.sundin@liu.se
} 
council in Europe foresees a potential increase in the remanufacturing industry, from its current turnover of $€ 30$ billion a year to $€ 90$ billion by the year 2030 [2]. These two insights bring thoughts on how industry and research now jointly need to change focus.

Remanufacturing has been defined in many ways; see, e.g., [4] and [5]. Within this paper, we adopt a broad definition of remanufacturing proposed by Östlin [6], based on Sundin [7], which says, "an industrial process whereby products, referred to as cores, are restored to useful life. During this process, the core passes through a number of operations, e.g., inspection, disassembly, part reprocessing, reassembly, and testing, to ensure it meets the desired product standards".

Remanufacturing is being performed by three types of remanufacturing companies, depending on their relation to the original equipment manufacturer (OEM). It could be the OEM itself that performs remanufacturing, or it could be a remanufacturer that is contracted by the OEM to perform remanufacturing for it, or, as in most cases, the remanufacturing company could be independent and have no collaboration with the OEM.

Remanufacturing is often seen as environmentally beneficial, since the efforts made when manufacturing new parts, e.g., material extraction, material manufacturing, part manufacturing and product manufacturing, are fully or partly salvaged when performing remanufacturing [8]. Based on seven studies within the EEE sector and according to Sundin and Lee [8], remanufacturing is preferable from an environmental perspective in comparison with new product manufacturing, since between $14 \%$ and $60 \%$ of environmental effects related to resource efficiency and $\mathrm{CO}_{2}$ equivalent emissions are reduced.

The remanufacturing industry currently relies significantly on manual work when, e.g., sorting and disassembling. Due to several issues, including process time and sequence, the number of operations, disassembly planning and scheduling, process cost, and performance measurement [9], it is challenging to stay competitive for many companies, particularly small and medium-sized enterprises (SMEs). As a result, it is assumed that more extensive use of robots and automation in these industries facilitates higher efficiency and better work conditions and, therefore, steadily contributes to an improved remanufacturing industry managing challenging issues. In addition, automation solutions allow working conditions where robots and humans interact and work closely together. Human-robot interaction is defined by Dautenhahn [10] as a highly inter- and multidisciplinary area. This is especially important in an industry sector like electronics remanufacturing, where some of the tasks can be performed by a robot, and others by a human. By enabling a human-robot collaboration (HRC), it is possible to mitigate monotonous and hazardous operations to a robot, while humans perform more flexible and cognitively challenging tasks, after performing risk assessments [11]. In February 2016, the technical specification ISO/TS15066 was released, and since then, robot suppliers have increased their product portfolios with new robots, like FANUC's CR-7 and Yaskawa's HC10, that have different safety functionality that could be utilized in a collaborative layout.

Previous research, e.g., by Kernbaum et al [12], has shown that automation in remanufacturing is hard to achieve in an economically feasible manner. However, robot technology developments and new needs for automation in remanufacturing have revived interest to raise the automation in remanufacturing question once more. Therefore, this paper aims to identify the automation potentials of the remanufacturing of EEE. 


\section{Research Methodology}

In order to reach the aim of this paper, a multiple case study at four remanufacturing companies located in Sweden was conducted. The companies studied are SMEs within the EEE industry (Table 1). These companies vary in terms of volume, product complexity, repair, and remanufacturing process. Their processes mainly include inspecting, cleaning, disassembling, reprocessing (repairing), reassembling, testing and packing.

Table 1. The characteristics of the companies included in the multiple case study of this paper.

\begin{tabular}{llll}
\hline Company & Product & Type of remanufacturer & Experience \\
\hline Company A & IT equipment & Independent & 21 years \\
\hline Company B & Photocopiers & Contracted & 36 years \\
\hline Company C & Toner cartridges & Independent & 26 years \\
\hline Company D & Car electronics & Contracted & 43 years \\
\hline
\end{tabular}

Companies' participation in this research was based on their intention to improve their repair and remanufacturing processes via an ongoing Swedish research project called Automated Repair and Remanufacturing (ARR). With a limited understanding of automation potentials in remanufacturing processes, the adopted case study methodology was found appropriate [13] to investigate and comprehend the applicability of automation on repair and remanufacturing processes of the case companies. Qualitative empirical data were gathered by means of direct observations, unstructured interviews and focus group discussions. The observation included a walkthrough at each company, allowing the authors to understand, e.g., repair and remanufacturing processes, internal logistics, product flow within the processes and remanufacturing challenges. During the walkthroughs and observations, notes and photos were taken and documented. In addition, a contact person guided, described the processes, and answered questions. During the focus group discussions, a specific company problem previously identified was discussed among several research project participants, both from industry and academia. The identification of the problems discussed in the focus groups was based on a general identified need for each industrial project partner. Afterwards, results were compared and analysed in an iterative and explorative nature to increase the understanding and generalizability of the empirical findings.

In addition to empirical studies, a literature search focused on research papers addressing automation within the repair and remanufacturing processes (e.g., Kernbaum et al [12]), even though research papers outside of this area tackling either automation or remanufacturing were included (e.g., Kurilova-Palisaitiene et al [9]). In addition, a qualitative downstream and upstream search of relevant references was also performed. The authors' experiences from previous research within remanufacturing and automation were also drawn from to build up theory within this area. 


\section{Theoretical framework}

\subsection{Remanufacturing of electric and electronic equipment}

The remanufacturing of EEE has been on the rise recently, following the industry sectors of aerospace and automotive, which have more extensive experience with remanufacturing. Within the European Union project called the European Remanufacturing Network, several EEE remanufacturers were investigated, including which process steps that are conducted in their remanufacturing (see Table 2) [14].

Table 2. Examples of process steps at European EEE remanufacturing companies (modified from [14]).

\begin{tabular}{|c|c|c|c|c|c|c|}
\hline Comp. & $\begin{array}{l}\text { Borg } \\
\text { Automotive }\end{array}$ & $\begin{array}{l}\text { Büroservice } \\
\text { Hübner }\end{array}$ & IT Lyftet & Leapp & ATP & ARP \\
\hline Product & $\begin{array}{l}\text { Electric } \\
\text { steering racks }\end{array}$ & Printers & Laptops & MacBook & $\begin{array}{l}\text { Trans- } \\
\text { missions }\end{array}$ & $\begin{array}{l}\text { Toner } \\
\text { cartridges }\end{array}$ \\
\hline $\begin{array}{l}\text { Reman } \\
\text { steps }\end{array}$ & $\begin{array}{l}\text { Disassembly, } \\
\text { Cleaning, } \\
\text { Inspection, } \\
\text { Recondition, } \\
\text { Replenishing, } \\
\text { Reassembly, } \\
\text { \& Testing. }\end{array}$ & $\begin{array}{l}\text { Testing, } \\
\text { Cleaning, } \\
\text { Part } \\
\text { changing, } \\
\text { \& Testing. }\end{array}$ & $\begin{array}{l}\text { Inspection, } \\
\text { Cleaning, } \\
\text { Inspection, } \\
\text { Data wiping, } \\
\text { Testing, } \\
\text { Replacing, } \\
\text { Reconfig., } \\
\text { \& Assembly. }\end{array}$ & $\begin{array}{l}\text { Quality } \\
\text { screen, } \\
\text { Decompose, } \\
\text { Inspection, } \\
\text { Repair, } \\
\text { Data wiping, } \\
\text { \& Packing. }\end{array}$ & $\begin{array}{l}\text { Inspection, } \\
\text { Teardown, } \\
\text { Cleaning, } \\
\text { Renewing, } \\
\text { Assembly, } \\
\text { \& Testing. }\end{array}$ & $\begin{array}{l}\text { Disassembly, } \\
\text { Cleaning, } \\
\text { Assemble } \\
\text { toner, } \\
\text { Refilling, } \\
\text { Assemble } \\
\text { cartridge, \& } \\
\text { Testing. }\end{array}$ \\
\hline
\end{tabular}

At the EEE remanufacturing companies, there is little or no automation ongoing within the process steps exemplified in Table 2 above [14]. As one can see from the examples in Table 2, there are several steps in different orders, depending on what kind of EEE is being remanufactured. However, according to Sundin and Bras [15], there are seven generic steps that a used product (a.k.a., core) goes through in order to become a remanufactured product (Figure 1).

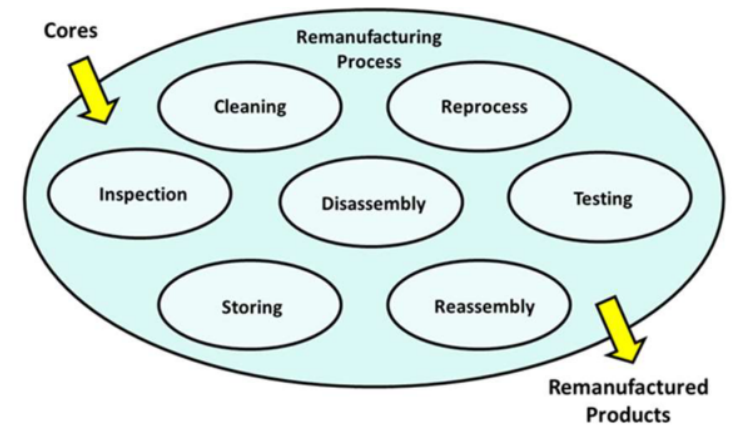

Figure 1. The seven generic steps included in a generic remanufacturing process [15].

\subsection{Collaborative industrial robot applications}

Industrial robots are traditionally surrounded by a safety fence, carrying out highly repetitive, monotonous tasks and heavy lifting operations in tough working environments while providing consistent quality, efficiency, and long cycle times [16, 17]. The processing steps in such an application often follow the same pattern with known 
parameters for quality, positioning and number of products: with a certain input, a given number of operations is carried out, which leads to a fixed output.

When dealing with the repair and remanufacturing of EEE, such input parameters are often not clear from the beginning; e.g., screws to disassemble a product can be dirty, rusty or broken. In the EEE industry, such tasks are almost all handled by humans, who can identify uncertainties and decided what to do for each product.

In order to utilize the advantages of robots, that is, endurance, flexibility, and accuracy, with those of humans, namely, intuition, flexibility and problem solving, human-robot collaboration (HRC) is needed [18]. HRC allows having collaborative applications where humans can work closely together with robots. Figure 2 depicts the various levels of cooperation. The cell configuration, to the far left in the figure, is that of a standard industrial robot in a cage where the human worker cannot interact with the robot. The other four configurations show different levels of interaction between a robot and a human worker. According to Gopinath and Johansen [11], after performing a risk assessment, it is possible to mitigate monotonous and hazardous operations to a robot while humans perform more flexible and cognitively challenging tasks.

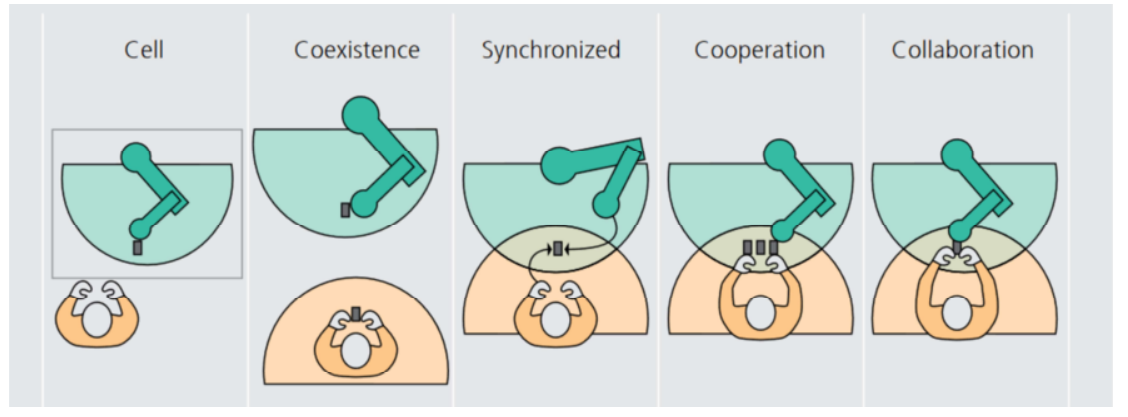

Figure 2. Various levels of cooperation between a human worker and a robot [19].

\section{Case study results}

\subsection{Company $A$}

Company A is an IT equipment remanufacturer that works to reinvent IT with the goal of contributing to a smarter consumption of IT equipment, such as computers, tablets, screens and smartphones. As laptops have the largest remanufacturing volume, and in a dialogue with the company, it was decided to only focus on laptops. The laptops are collected through customers, e.g., companies, in cabinets (Figure 3a). These cabinets are packed with IT equipment in different ways, depending on the customer. For example, the cables can be placed on one shelf and all other IT equipment placed on other shelves. The process of remanufacturing laptops was mapped and contained the following steps:

1. Laptops are removed from the cabinets.

2. a) Laptops are registered and individually labelled.

b) Cables are untangled, rewound and sorted.

3. Laptops and cables are buffered before the next step.

4. Laptops are sent to a workplace for erasing all data (Figure 3b) - if not possible, the system signals and the non-erasable hard disc drives are removed and mechanically destroyed. 
5. Laptops are visually controlled and cleaned if needed or possible, and thereafter sorted into different classes before being moved to ready-to-sell storage.
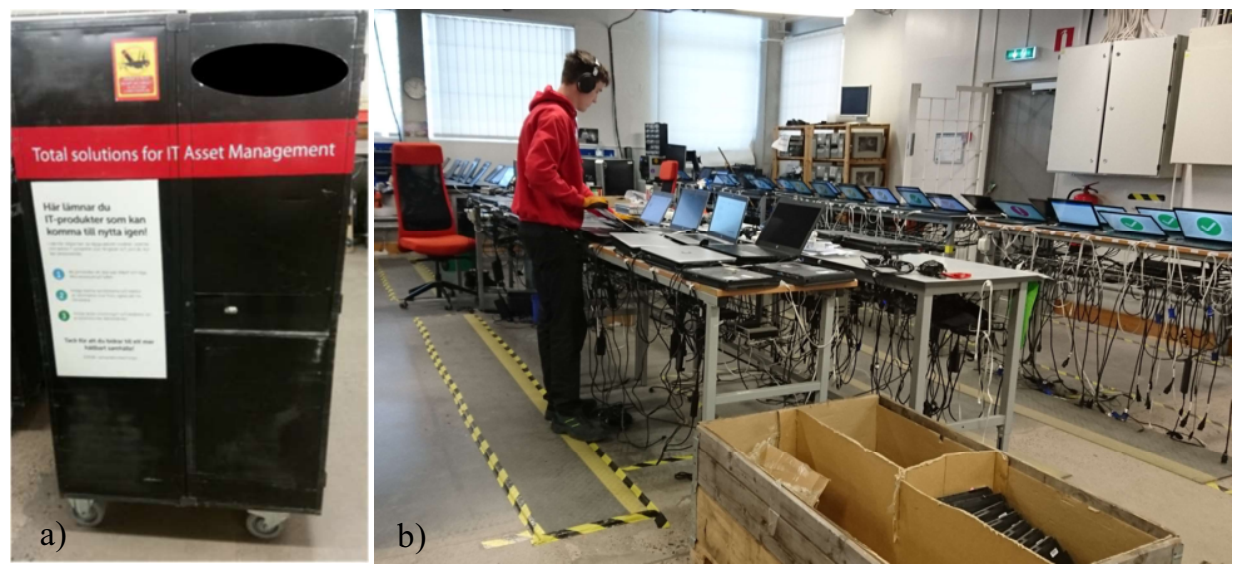

Figure 3. a) An example of a cabinet used to collect IT equipment for remanufacturing at Company A.

b) Workplace for erasing data from laptops at Company A.

After this initial process, the laptops are stored for sale. When a product is bought, the final customization is done. For a normal customer, this activity is divided into the following two steps: (1) reconfigure the laptops and install the operating system, and (2) pack the laptops with cables and deliver them to the customer.

\section{Potential for automation at Company A}

The entire remanufacturing process at company A is currently manual. The potentials for automation in this remanufacturing process are identified and presented in Table 3.

Table 3. The identified potential processes for automation at Company A, where the source and the automation reasons are described. $\mathrm{WE}=$ Work Environment, $\mathrm{O}=$ Observations, $\mathrm{I}=$ Interviews, $\mathrm{F}=$ Focus group discussion. The source of data and automation reasons are given in order of appearance.

\begin{tabular}{lll}
\hline Process step & Reason for automation & Source of data \\
\hline Rewinding of laptop cables (strenuous for hand wrists) & WE and Efficiency & I, O and F \\
\hline Placing, connecting and setting up laptops for data erasing & Efficiency & O, I and F \\
\hline Accessing laptops for data erasing & Efficiency & O and F \\
\hline $\begin{array}{l}\text { Disconnecting and picking up laptops for buffering } \\
\text { classification (sorting) }\end{array}$ & Efficiency & O, I and F \\
\hline Destruction of non-erasable hard disc drives & Efficiency & I and O \\
\hline Raising boxes for packing the remanufactured laptops & Efficiency & O and I \\
\hline
\end{tabular}

\subsection{Company $B$}

Company B is one of the largest remanufacturers of photocopiers in Europe. Its incoming products are usually purchased from markets in Europe with logistics centres in Sweden and Germany, and after remanufacturing, they are sold to 60 different countries. Company B remanufactures almost all copy machine brands and models, which accounts 
for a total of 6000-7000 tons per year. Its focus is also on black and white photocopiers. The main challenges of its whole business are described as having a stable flow of incoming products, which strongly varies seasonally, and a variety of incoming products, which is usually unknown when the company is purchasing.

Looking at its general repair and remanufacturing process, it includes identifying and tagging, inspection and testing, erasing hard disc drives, sorting and separation, disassembly, repair and component exchange, final testing, cleaning and packaging. Parts and components that cannot be repaired and remanufactured are sent for material recycling.

The studied process at the company for this research is the toner cartridges refilling process, which is currently mainly carried out manually, with an average of 60 refills per day. The refilling is conducted based on model and colour. The toner cartridges refilling process includes (1) emptying, (2) sorting, (3) refilling toner cartridges with the help of a machine (Figure 6c), (4) sealing, (5) cleaning, (6) marking and (7) packing (Figure 4).
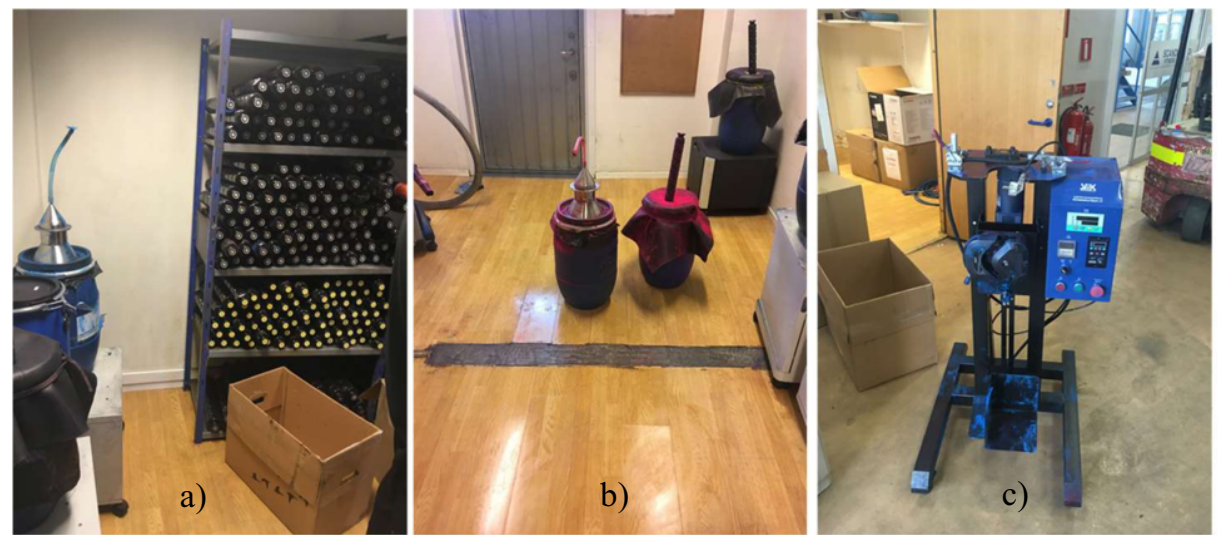

Figure 4. Equipment used for emptying and refilling toner cartridges at Company B:

a) storage of sorted toner cartridges, b) barrel for recovered toner and c) refilling machine.

\section{Potential for automation at Company B}

Based on the data collected at Company B, the potentials for automation in this remanufacturing process are identified and presented in Table 4.

Table 4. The identified potential processes for automation at Company B, where the source and the automation reasons are described. WE=Work Environment, $\mathrm{O}=$ Observations, $\mathrm{I}=$ Interviews, $\mathrm{F}=$ Focus group discussion. The source of data is mentioned in order of appearance.

\begin{tabular}{lll}
\hline Process step & Reason for automation & Source of data \\
\hline $\begin{array}{l}\text { Emptying toner cartridges (recovering the toner) - a work } \\
\text { environment issue in the form of powder contamination } \\
\text { (hazardousness) }\end{array}$ & WE and Efficiency & O and F \\
\hline $\begin{array}{l}\text { Refilling toner cartridges } \\
\text { - a work environment issue in the form of ergonomic }\end{array}$ & WE and Efficiency & I, O and F \\
$\begin{array}{l}\text { issues and repetitive work } \\
\text { - a precision requirement, as colours and toners must not } \\
\text { be mixed. In addition, toner cost is high, and toner waste } \\
\text { has economic drawbacks }\end{array}$ & & \\
\end{tabular}




\begin{tabular}{lll}
\hline Process step & Reason for automation & Source of data \\
\hline $\begin{array}{l}\text { Cleaning toner cartridges (on the outside after being } \\
\text { refilled) - a customer requirement to have a clean toner } \\
\text { cartridge (quality issue) }\end{array}$ & Quality and WE & O and F \\
\hline
\end{tabular}

\subsection{Company $C$}

Company $\mathrm{C}$ is the largest remanufacturer of printer cartridges in Scandinavia, with customers throughout Europe. Company $\mathrm{C}$ remanufactures almost all toner cartridges from various brands and models. The main challenges of its business are described as having a high variety of incoming products with smaller batches, which in turn increases the set-up time.

Looking at its general remanufacturing process, it includes (1) collection and sorting, (2) disassembly, (3) inspection, (4) emptying and cleaning, (5) drilling (if needed), (6) repair and refilling toner, (7) reassembly, (8) testing, (9) resetting and coding and (10) packaging. Parts and components that cannot be repaired and remanufactured are sent for material recycling.

The whole remanufacturing process at Company $\mathrm{C}$ is currently carried out manually, mainly due to a high variety of cartridge models with different shapes and forms as well as the way they are being disassembled and refilled. Based on mapping and studying the remanufacturing processes and several back-and-forth discussions, it was concluded that the emptying and cleaning, as well as refilling, have the highest automation potentials, mainly owing to efficiency and work environment reasons (see Figure 5).
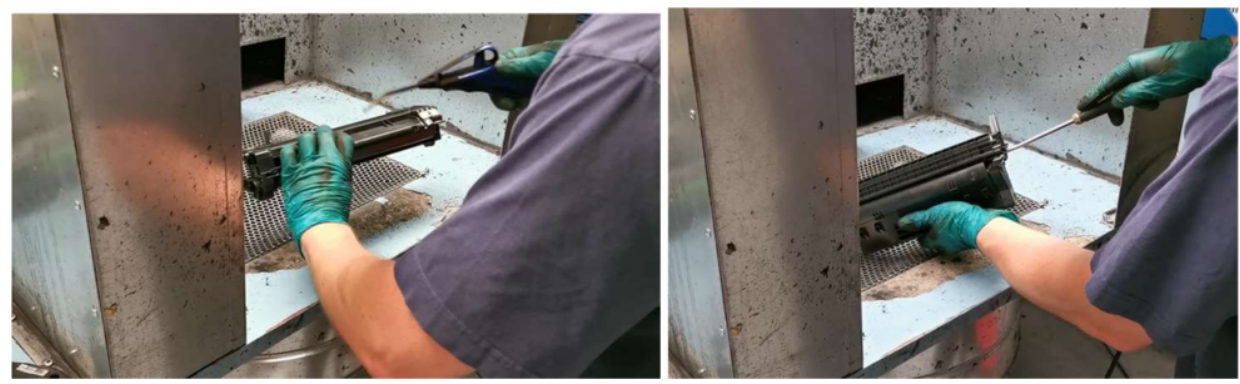

Figure 5. Cleaning and disassembling toner cartridges at Company C.

\section{Potential for automation at Company $\mathrm{C}$}

Based on the data collected at Company C, the potentials for automation in this remanufacturing process are identified and presented in Table 5.

Table 5. The identified potential processes for automation at Company $\mathrm{C}$, where the source and the automation reasons are described. WE=Work Environment, $\mathrm{O}=$ Observations, $\mathrm{I}=$ Interviews, $\mathrm{F}=$ Focus group discussion. The source of data is mentioned in order of appearance.

\begin{tabular}{lll}
\hline Process step & Reason for automation & Source of data \\
\hline $\begin{array}{l}\text { Cleaning toner cartridges - a work environment issue in } \\
\text { the form of noise from the fume hood space, ergonomic }\end{array}$ & WE and Efficiency & I, O and F \\
issues and repetitive work for the operator & & \\
\hline
\end{tabular}




\begin{tabular}{lll}
\hline Process step & Reason for automation & Source of data \\
\hline Refilling toner cartridges & WE and Efficiency & O, I and F \\
- a work environment issue in the form of ergonomic & & \\
issues and repetitive work & & \\
- a precision requirement, as colours and toners must not & \\
be mixed. In addition, toner cost is high, and toner waste & \\
has economic drawbacks & \\
\hline
\end{tabular}

\subsection{Company D}

Company D is specialized in the repair and remanufacturing of electronic components for cars, e.g., infotainment systems and electronic components for engines. Company D is part of the value chain of a major automobile manufacturer. This means the automobile manufacturer's service network collects defective components and markets the remanufactured product.

This study focuses on an electro-mechanical component of an engine (Figure 6). Other components with similar characteristics that are currently manufactured or are planned to be remanufactured are also considered. The component consists of a mechanical structure, mechanisms and integrated electronics. Automation is facilitated as the components are mechanically robust and dimensionally stable, which supports handling and fixturing. The process of remanufacturing the electro-mechanical components was mapped and contained the following nine steps:

1) Inspecting and testing

2) Cleaning

3) Machining off lid

4) Disassembling and cleaning

5) Removing sealant

6) Repairing electronics

7) Applying sealant

8) Assembling new lid

9) Testing

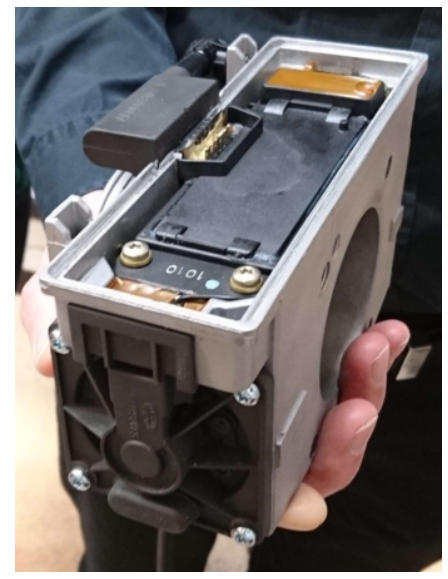

Figure 6. The electro-mechanical component remanufactured at Company D.

The studied components require sealing to protect their insides from the harsh environment, e.g., in the engine compartment of a car. Therefore, the components must be resealed during remanufacturing. Sealants are commonly used in these applications. For this reason, related recurring process steps are separating the components, which may be realised by cutting the seal, removing the remaining cured sealant, and dispensing of the new sealant, which then has to be cured. Currently, these process steps are performed manually; removing the remaining cured sealant is especially tedious work.

\section{Potential for automation at Company D}

Based on the data collected at Company D, the potentials for automation in this remanufacturing process are identified and presented in Table 6. 
Table 6. The identified potential processes for automation at Company $\mathrm{C}$, where the source and the automation reasons are described. WE=Work Environment, $\mathrm{O}=$ Observations, $\mathrm{I}=$ Interviews, $\mathrm{F}=\mathrm{Focus}$ group discussion. The source of data is mentioned in order of appearance.

\begin{tabular}{lll}
\hline Process step & Reason for automation & Source of data \\
\hline Cleaning electro-mechanical component & WE and Quality & O, I and F \\
\hline $\begin{array}{l}\text { Removing the sealant from the electro-mechanical } \\
\text { component }\end{array}$ & Efficiency and WE & O, I and F \\
\hline $\begin{array}{l}\text { Sealing the electro-mechanical component - mainly } \\
\text { precision work }\end{array}$ & Efficiency and Quality & O, I and F \\
\hline
\end{tabular}

\section{Cross-case analysis}

Using the theoretical framework regarding the seven generic process steps of remanufacturing [15] and the levels of HRC [19], combined with empirical data collected from the case companies (Section 3) and also the authors' different previous experiences on several aspects of automation and remanufacturing, including their environmental and production system challenges, we can summarise the potential for automation at the studied remanufacturing companies. The cross-case analysis presented in Table 7 below links the generic process steps (Figure 1) to empirically identified applications in each case company (Tables 3-6) and also to the levels of HRC (Figure 2). The automation potentials identified reflect the possibility for applications in the existing production system where the operators might interact with a robot differently. However, this analysis is the primary result of our iterative dialogue with the industrial partners regarding increased automation within the remanufacturing industry.

Table 7. The identified potential for automation at the case companies of this research.

Potential levels of HRC are given in parentheses.

\begin{tabular}{lcccc}
\hline Remanufacturing step & Company A & Company B & Company C & Company D \\
\hline Inspection & $\begin{array}{c}\text { Data erasing } \\
(N / A)\end{array}$ & $\begin{array}{c}\text { Cleaning } \\
\text { (Cell) }\end{array}$ & $\begin{array}{c}\text { Cleaning } \\
\text { (Synchronized) })\end{array}$ & $\begin{array}{c}\text { Cleaning } \\
\text { (Cooperation) }\end{array}$ \\
\hline Cleaning & $\begin{array}{c}\text { Disconnect laptops } \\
(N / A)\end{array}$ & $\begin{array}{c}\text { Emptying } \\
\text { (Coexistence) }\end{array}$ & $\begin{array}{c}\text { Remove sealant } \\
\text { (Cell) }\end{array}$ \\
\hline Disassembly & Connect laptops for \\
data erasing $(N / A)$ & Refill & (Coexistence) & $\begin{array}{c}\text { Refill } \\
\text { (Coexistence) }\end{array}$ & $\begin{array}{c}\text { Sealing } \\
\text { (Coexistence) }\end{array}$ \\
\hline Reassembly & & & \\
\hline Testing & Raising boxes (Cell) & & \\
\hline Packing & & & \\
\hline
\end{tabular}

As shown in Table 7, cleaning, disassembly and reassembly have the main automation potentials in general. The main potential automation incentive for these remanufacturing processes concerns the work environment in the cleaning steps, but also when refilling toner at the assembly steps (Companies B and C). The other potentials are driven more by acquiring a precision that a robot may achieve (Company D) or by increasing the process efficiency (Company A). Quality is also a driver for automation, as was identified in Companies B and D. 


\section{Discussion and conclusion}

Based on the case study and the literature, we can find motives to automate remanufacturing for similar reasons as in ordinary manufacturing, e.g., to achieve more efficient processes with shorter lead times. However, much potential was found in the cases in the cleaning steps for work environment reasons. This is a process step that usually needs much attention in remanufacturing, as is it often very time-consuming and has a high share of the process lead time for the entire remanufacturing process (e.g., Sundin and Bras [15]).

In addition, previous research has shown that it is sometimes hard to implement robots in remanufacturing due to long process times (e.g., Kernbaum et al [12]). However, there are opportunities and installations that are successful when it comes to, e.g., the cleaning and assembly of automotive parts at Autocraft [20]. In our study of EEE products, we have found potentials for automation, especially in the cleaning and assembly steps.

However, according to Wang et al [18], it is important to balance the advantages of robots with the skills of a human in order to develop an efficient HRC, and as stated by Bauer [19], there are five different levels of collaboration which need to be reflected around. These different levels indicate that there is a close relation between the preferred layout and the task to be done. This can be exemplified with our cleaning process for Company $\mathrm{D}$, where the removal of sealant might need to be done with a very sharp tool. If that tool is in the robot end-effector, the risk assessment [11] will indicate more hazards, and therefore promote a cell layout philosophy due to safety reasons, which can be related to work environment challenges.

\section{Future research}

Based on this performed mapping of the EEE remanufacturing industry, we have identified several challenges left for future research. We can see the need for further indepth technology demonstrator development in order to reflect which way might be the most beneficial as well as efficient to increase the automation in remanufacturing applications. However, the companies in the case studies have one issue in common: the need for technology flexibility while investing in more automated solutions, since, e.g., the volumes are low for each type of product, many variants need to be managed and there is so much diversity in incoming quality. Furthermore, it is important to invest in automated solutions that can contribute to both economic as well as environmental effects. The studied companies were mainly SMEs and, therefore, future research might include a large remanufacturer. In addition, the connection of the remanufacturing process steps and potential automation levels of HRC needs to be further investigated in detail. For example, we can see a pattern where reassembly at three of the case companies (B-D) can only adopt coexistence HRC, while the fourth remanufacturing company (A) did not follow this pattern. 


\section{Acknowledgements}

The authors wish to thank the remanufacturing companies included in the research of this paper and the financial support of the strategic innovation programme called "Produktion2030", which is funded by the Swedish Government Innovation Agency (VINNOVA), Formas and the Swedish Energy Agency.

\section{References}

[1] Ellen MacArthur Foundation, SUN, and McKinsey Center for Business and Environment, Growth within: a circular economy vision for a competitive Europe. 2015.

[2] European Remanufacturing Council, 2020, https://www.remancouncil.eu. Accessed March 02, 2020.

[3] World Economic Forum, Launch of Climate Action Platform for Delivering Carbon Neutrality in Hardto-Abate Sectors by Mid-Century. 2020, https://www.weforum.org. Accessed March 2, 2020.

[4] M. Thierry, M. Salomon, J. Van Nunen, and L. Van Wassenhove, Strategic Issues in Product Recovery Management, in California Management Review, Vol. 37(2), 1995, pp 114-135.

[5] R. Lund, The Remanufacturing Industry: Hidden Giant, 1996, Boston University, Boston, MA.

[6] J. Östlin, On Remanufacturing Systems: Analysing and Managing Material Flows and Remanufacturing Processes, Linköping Studies in Science and Technology, Thesis No. 1192, UniTryck, Linköping, 2008.

[7] E. Sundin, Product and process design for successful remanufacturing, Linköping Studies in Science and Technology, Dissertation No. 906, Tabergs Tryckeri AB, Taberg, 2004.

[8] E. Sundin E and H.M. Lee (2011) In what way is remanufacturing good for the environment? Proceedings of the $7^{\text {th }}$ International Symposium on Environmentally Conscious Design and Inverse Manufacturing (EcoDesign-11), November 30 - December 2, Kyoto, Japan, pp 551-556.

[9] J. Kurilova-Palisaitiene, E. Sundin, and B. Poksinska, Remanufacturing challenges and possible lean improvements. Journal of Cleaner Production, Vol. 172, 2018, pp 3225-3236.

[10] K. Dautenhahn, Socially intelligent robots: dimensions of human-robot interaction. Philosophical transactions of the royal society B: Biological sciences, Vol. 362(1480), 2007, pp 679-704.

[11] V. Gopinath, and K. Johansen, Understanding situational and mode awareness for safe human-robot collaboration: case studies on assembly applications, Production Engineering, Vol. 13(1), 2019, pp 1-9.

[12] S. Kernbaum, C. Franke, and G. Seliger, Flat screen monitor disassembly and testing for remanufacturing. International Journal of Sustainable Manufacturing, Vol. 1(3), 2008, pp 347.

[13] R.K. Yin, Applications of Case Study Research, 2003, Sage Publications.

[14] E. Sundin, T. Sakao, M. Lindahl, C.-c. Kao and B. Joungerious, Map of Remanufacturing Business Model Landscape. European Remanufacturing Network, www.remanufacturing.eu, 2017.

[15] E. Sundin, and B. Bras, Making functional sales environmentally and economically beneficial through product remanufacturing. Journal of Cleaner Production, Vol. 13(9), 2005, p. 913-925.

[16] Robots and robotic devices - Safety requirements for industrial robots - Part 1: Robots/ Part 2: Robot systems and integration, International Organization for Standardization, ISO, 10218-1/2, 2011.

[17] M. Wilson, Implementation of robot systems: an introduction to robotics, automation, and successful systems integration in manufacturing, 2014, Butterworth-Heinemann.

[18] L. Wang, R. Gao, J.Váncza, J. Krüger, X.V.Wang, S. Makris and G. Chryssolouris, Symbiotic humanrobot collaborative assembly. CIRP annals, 2019, 68(2), pp 701-726.

[19] W. Bauer, M. Bender, M. Braun, P. Rally, and O. Scholtz, Lightweight robots in manual assembly - best to start simply, Fraunhofer - Institut für Arbeitswirtschaft und Organisation IAO, Stuttgart, 2016.

[20] M. Hague-Morgan, The power of Digital Manufacturing and Robotics to Revolutionise Traditional Reman Processes, in To Elevate Automotive Remanufacturing by Innovation and Automation, Editor F.J. Weiland, Dukarnia The printing house, 2019, pp 133-144. 